\title{
Demand organization in public oral health services: analysis of a traditional model
}

\author{
Organização da demanda em serviç̧os públicos de saúde bucal: análise de um modelo tradicional
}

\author{
Angelo Giuseppe RONCALLI ${ }^{1}$ \\ Suzely Adas Saliba MOIMAZ² \\ Adrielle Mendes de Paula GOMES² \\ Cléa Adas Saliba GARBIN² \\ Nemre Adas SALIBA ${ }^{2}$
}

\section{ABSTRACT}

\section{Objective}

To discuss the municipal experience of the organization and the demand for dental services, based on the guidelines of the Unified Health System (UHS), which point to the structuring of an assistance model based on universality and integrality of care and equity in access to services.

\section{Methods}

The research, realized in Araçatuba/SP, was based on documentary analysis and interviews with key-informants of the UHS dental service. The traditional court model has a care system for schoolchildren and a basic network with priority for pregnant women.

\section{Results}

In total, the network has 59 dental surgeons, 31 oral health auxiliaries and 17 Oral Health Teams; however, the school attendance model persists, with 10 professionals attending public schools. Based on the discussions, it is concluded that there are no established criteria for the organization of demand.

\section{Conclusion}

Most of the attendance occurs by free demand, and the reference and counter-referral system is incipient, damaging the service's resoluteness.

Indexing terms: Dental health services. Oral health. Public health. Unified Health System.

\section{RESUMO}

\section{Objetivo}

Discutir a experiência municipal da organização a demanda de serviços odontológicos, com base nas diretrizes do Sistema Único de Saúde (SUS), as quais apontam para a estruturação de um modelo assistencial com base na universalidade e na integralidade da atenção e na equidade no acesso aos serviços.

\section{Métodos}

A pesquisa, realizada em Araçatuba (SP), teve como base a análise documental e entrevistas com informantes-chave do serviço odontológico do SUS. O modelo de corte tradicional, conta com um sistema de assistência para escolares e uma rede básica com prioridade para gestantes.

\section{Resultados}

No total, a rede conta com 59 cirurgiões-dentistas, 31 auxiliares em saúde bucal e 17 Equipes de Saúde Bucal, entretanto persiste o modelo de atendimento a escolar, com 10 profissionais atendendo em escolas públicas. A partir das discussões colocadas, conclui-se que, não há critérios estabelecidos para organização da demanda.

\section{Conclusão}

A maioria dos atendimentos ocorre por livre demanda, e o sistema de referência e contra-referência é incipiente, prejudicando a resolutividade do serviço.

Termos de indexação: Serviços de saúde bucal. Saúde pública. Saúde bucal. Sistema Único de Saúde.

\footnotetext{
${ }^{1}$ Universidade Federal do Rio Grande do Norte, Departamento de Odontologia. Av. Salgado Filho, 1787, Lagoa Nova, 59056000, Natal, RN, Brasil. Correspondência para / Correspondece to: AG RONCALLI. E-mail: <roncalli@ufrnet.br>.

${ }^{2}$ Universidade Estadual Paulista "Júlio de Mesquita Filho, Faculdade de Odontologia. Araçatuba, SP, Brasil.
} 


\section{INTRODUCTION}

Access to oral health services in Brazil is still one of the major problems to be addressed by public health service delivery systems. The accumulated experience of exclusionary models, put in check by the implantation of the Unified Health System (UHS) at the end of the 1980s, has had a process of revision and reformulation still slow, even considering the short time of existence of a model based in the universality of attention.

An important aspect in the implementation of any model of oral health care is the organization of demand. Historically, Dentistry in the field of Collective Health has experimented with several formulas of demand organization, which, for the most part, work from prioritized groups or from spontaneous demand ${ }^{1-5}$.

The expanded concept of health and the explanation in article 196 of the Federal Constitution of 19886, "health as a right of all and duty of the State", is a watershed within the historical construction of health policies in Brazil and Public Policies, with implications also for oral health, which has come to be understood as an inseparable dimension of health. It was the end of a cycle that was marked by exclusionary welfare policies, reflecting a regulated citizenship and a repressive state ${ }^{7-9}$.

One of the recommendations of the II National Oral Health Conference is that "the programming of dental care (...) should be integrated with health programs and use social and epidemiological criteria with the participation of the community to establish priorities that do not imply social exclusion" 10 . These recommendations were reaffirmed at the III Conference, emphasizing that the organization of oral health care should "ensure and expand access to comprehensive oral health actions throughout the UHS (...) taking into account regional epidemiological data" 11 .

In this way, one of the major conflicts facing the organization of dental care today is to maintain the rationality and practicality of care for prioritized groups without, however, compromising universality and, in addition, maintaining the characteristics of an effective and resolute system ${ }^{12-13}$.

\section{Public dental care in Brazil}

A quick historical rescue shows that, in the last 50 years, the country has experimented with several formulas for the organization of public services in the dental area. It has been structured, basically, from the classic models of assistance to schoolchildren, recommended by SPHS (Special Public Health Services) in the 1950s, and by attending to free demand in health units, until the establishment of the Health Unic System in the constitutional text of $1988^{1,3}$.

Most of the authors consider that, until 1952, the school dental care, and even public care in general, was marked by an eminently rudimentary phase, particularly with regard to planning and the type of service offered.

For Zanetti et al. ${ }^{2}$, these first forms of dental care in the public sector were characterized as being a practice of free demand and without a programmatic logic defined so that the scientific programming in oral health only arose even in the 1950s, with the SESP introduction of assistance models to the schoolchildren.

In spite of having introduced a more scientific organizational logic from the programming point of view, the conceptions of dental practice in the SESP programs did not break with the hegemonic model, which had, as ideological, the movement of Dentistry Sanitary and, as a programmatic proposal, the Incremental System of care for schoolchildren?.

For Narvai', the theoretical reference of Sanitary Dentistry shows a clear influence of the American and British Public Health Dentistry, which had a significant influence in their countries as a component strategy of public policies aimed "to respond to social pressures and to contain the 'advance of communism". They had, therefore, residual character with low coverage and little epidemiological efficacy. It was also conformist because it was resigned to the condition of "state assistance alternative for the poor and needy of the priority population groups".

Among the models of oral health for schoolchildren implemented in the USA, the most developed and expanded in Brazil and Latin America was the Incremental System. First conceived in the city of Richmond, in 1946, it was employed in Brazil for the first time in Aimorés/MG by SPHS.

In spite of being a programmatic model, that is, in theory could be applied to any circumscribed clientele, the Incremental System became synonymous with the model of care in oral health (in fact, a model of assistance to schoolchildren) and has remained as hegemonic for more than 40 years.

Narvai ${ }^{1}$ warns that the Incremental System does not constitute a care model, but only a care system, however due to its great expansion and uncritical replication it ended up being confused with the dental school programs. For this author, the criticisms that go to 
Incremental, most often do not address the system itself, but "managerial precariousness, lack of resources and lack of epidemiological approach to programs." Still according to the author, it is fundamentally an exclusionary model and an excessively individual approach.

For Loureiro \& Oliveira ${ }^{14}$, the Incremental System was based on the prevention of dental caries and curative assistance in dealing with those already existing. It has the logic of models based on "cure" and not on disease control. Most of the time a modification is achieved between the carious and obturated components of the DMFT and not a reduction in the prevalence.

In spite of these criticisms, the Incremental System was an experience that, at the time when it was thought, was the most modern and constituted an important effort to apply health programming techniques 15 . It was an opening pole that was defined at that time by the accumulation of available knowledge.

Despite being a totally exhausted system today, Incremental has become a milestone in oral health programming, serving as the basis for practically all experiences of dental services organization for schoolchildren and has gone through all these years without any substantive criticism²,15-16.

Thus, between the 1950s and the end of the 1980s, public dental care in Brazil was characterized by the fact that it had a predominant model of care for schoolchildren (mostly with the Incremental System) and, for the rest of the population, the assistance was given in a pulverized way among the various institutions, including those agreed with the Social Security System (SSS), the State Secretaries of Health and philanthropic entities ${ }^{1,3}$.

In the area of public assistance, dental care has been present since the emergence of CAPs and IAPs as institutions providing health services in the scope of social security. From the mid-1960s, with the merger of the IAPs into the INPS, there is a growing expansion of dental care at the state level. In the 1980s, the Plan for the Reorientation of Dental Care (PRDC), referred by Botazzo et al. ${ }^{17}$ as "Conaspinho", was approved with the ABASS (Advisory Board for the Administration of Social Security) Plan. From then on, and with the advent of the Integrated Health Actions (IHA), "hundreds of oral health programs were created and developed in state and municipal health secretariats throughout the country" 1 .

The growth of the state dental care network, however, continued with the same logic of a flexnerian practice and a programmatic model centered on free demand ${ }^{2}$.
The health care models in general and oral health in particular, with municipal coverage, have become of greater importance since the creation of the Unified Health System (UHS) with the increasing increment in the municipalization of health actions. SUS also brings in its core the principle of universality of attention, integrality and decentralization of actions and social control. They are guidelines that put the current models in check and place a great challenge on the municipalities that have proposed to reorganize their care models ${ }^{18-19}$.

Although the school-based Incremental System is only a programmatic model with clear limitations, it formed a very solid and "comfortable" basis for most municipalities. With the need to create a new system, from other bases, many municipalities were somehow "orphans of the incremental " and had to elaborate their own models of care. Although some alternatives have emerged since the 1970s, such as Simplified Dentistry and Integral Dentistry, which generated clones all over the country, these models (which, in fact, did not break the programmatic logic of the school model) did not were consolidated, except in some specific experiences.

Several municipalities have formulated care models in many different ways. Some municipal experiences have stood out since the beginning of the 1990s, due to the fact that they have established models that are consistent with SUS principles, but also because they have developed very efficient programmatic structures and have achieved significant results in reducing major oral diseases in a reasonable short period.

The purpose of this study was to analyze the municipal experience of the network of assistance to Oral Health in the SUS and to investigate the changes in strategies of demand organization.

\section{METHODS}

In the field phase, documentary research was used, where aspects related to the organization of the demand in the municipality were analyzed, complemented by interviews with key-informants, people directly involved in the elaboration of the models, technicians and authorities responsible for their implementation and professionals (dentists and dental assistants) who provide care. Epidemiological data and services related to the main evaluative indicators were also researched, in order to establish a critical analysis of the model. 


\section{RESULTS}

\section{The Health Care System}

Araçatuba, a municipality in the northwestern region of São Paulo, distant $533 \mathrm{~km}$ from the capital, has a population estimated for 2014 of 191,662 inhabitants ${ }^{20}$.

Health care in Araçatuba is municipalized. The annual value fixed PAB is almost 3.9 million, which gives an expenditure of just over 20 reais per inhabitant per year in basic assistance, according to data from $2013^{21}$. Overall, the per capita health expenditure for 2009 was $\mathrm{R} \$ 341.56^{22}$.

Araçatuba is the seat of the Regional Directorate of Health (RDH) II that encompasses 40 municipalities in the northwest region of the State. With regard to the physical outpatient network, the municipality has, in all, 61 units between Health Centers and Health Units, which belong to the public network. The hospital network consists of a public hospital and philanthropic providers, with a proportion of beds per 1,000 inhabitants of $2.59^{23}$.

From the point of view of physical and human resources, the network of dental services in Araçatuba now has 59 dental surgeons, of which 10 are still remnants of the Dental School and continue to attend public schools. Dental surgeons are distributed in Dental Care Units (DCU), Family Health Strategy (FHS) and schools, with 32 dental surgeons in 10 DCU, 17 dental surgeons in 12 FHS and 10 dental surgeons in 10 schools. Table 1 explains the dental procedures performed according to the care unit in the municipality of Araçatuba in the year 2013.

With regard to secondary care, the system has a Center of Dental Specialties (CDS), which offers treatment in the specialties of endodontics, total prosthesis, surgery and periodontics. Inaugurated in 2004, the CDS has 7 dental surgeons specialists, working in 4 offices. Patients are referenced to the health units of origin by means of a manually completed form; there is no computerized reference / contra-referral system to control patient scheduling, as this is where the CDS has to go to schedule. Patients are scheduled according to the order of arrival, prioritizing the elderly patients. According to CDS's professionals, approximately $40 \%$ of scheduled patients do not attend consultations. At the end of the treatment, only patients treated in the endodontic specialty are counter-referenced to the home health unit to complete the restorative dentistry treatment, if applicable.
Table 1. Dental procedures performed in the municipality of Araçatuba in the year 2013 according to the care unit. Araçatuba (SP), 2013.

\begin{tabular}{|c|c|c|c|c|}
\hline PROCEDURE & $\begin{array}{c}\mathrm{DCU} \\
(\mathrm{N}=09)\end{array}$ & $\begin{array}{c}\text { FHS } \\
(\mathrm{N}=12)\end{array}$ & $\begin{array}{c}\text { DENTAL } \\
\text { SCHOOL } \\
(\mathrm{N}=10)\end{array}$ & TOTAL \\
\hline Consultations & 7.171 & 10.443 & 5.118 & 22.732 \\
\hline Urgent Care & 14.929 & 10.753 & 367 & 26.049 \\
\hline $\begin{array}{c}\text { First } \\
\text { Consultation }\end{array}$ & 2.102 & 7.667 & 1.716 & 11.485 \\
\hline Restorations & 8.880 & 28.268 & 2.290 & 39.438 \\
\hline $\begin{array}{l}\text { Endodontic } \\
\text { Treatments }\end{array}$ & 5.164 & 1.353 & 781 & 7.298 \\
\hline Extractions & 1.949 & 4.094 & 235 & 6.278 \\
\hline $\begin{array}{c}\text { Periapical } \\
\text { Radiography }\end{array}$ & 1.297 & 1.960 & 23 & 3.280 \\
\hline $\begin{array}{l}\text { Preventive } \\
\text { Measures }\end{array}$ & 15.758 & 28.677 & 12.677 & 57.112 \\
\hline $\begin{array}{l}\text { Abscess } \\
\text { Drainage }\end{array}$ & 2.744 & 281 & 3 & 3.028 \\
\hline $\begin{array}{c}\text { Small } \\
\text { Surgeries }\end{array}$ & 1.928 & 1.849 & 6 & 3.783 \\
\hline Speeches & 30 & 135 & 17 & 182 \\
\hline $\begin{array}{c}\text { Supervised } \\
\text { Collective } \\
\text { Actions }\end{array}$ & 11 & 4.147 & 1.163 & 5.321 \\
\hline Total & 61.963 & 99.627 & 24.396 & 185.986 \\
\hline
\end{tabular}

Note: Source: Araçatuba City Hall - Municipal Health Secretariat, 2013.

Still in relation to secondary care, the FOA maintains an agreement with the secretariat and works as a SUS provider, attending patients by free demand, in health clinics.

FOA also maintains a maternity service, with a clinic in the dependencies of the Department of Child and Social Dentistry and clinics in two social entities of the municipality.

The flow of patients to the pregnant women's clinic is made from referrals of the prenatal programs of the basic network and on-site work in the Health Units carried out by the trainees with educational and preventive activities. Thus, all pregnant women who seek the service go through health education activities.

At the end of gestation, the mothers are then referred with their babies to the county's baby clinic. For coordination of the program, the articulation with the basic network was initially very difficult, since the pregnant women looked for the service only in the last month to guarantee the attendance after the childbirth. Greater articulation with the professionals of the network was made in the sense of motivating for a greater participation. Nevertheless, it is considered as one of the "critical nodes" of the system the little articulation that exists of the dentistry with the other areas.

The Baby Clinic of the municipal network, according to municipal coordination, was one of the first experiences of this type to be incorporated into the basic 
network in Brazil. Inaugurated in 1991, it served the entire population of the municipality through the system of free demand (mothers and their respective babies). There were no criteria to determine which ones would be served or no, neither age limits for the babies to be attended to. For the professionals of the network, the clinic had a good acceptability of the population, and the mothers always returned to the maintenance of the preventive treatment that followed, in general terms, the philosophy of work proposed by the pioneering experiences of dentistry for babies.

The Baby Clinic, formerly located in the Santana neighborhood, was unoccupied for presenting problems in the structure of the building. Currently, it has five dentists to attendance. Until the month of April 2010, care was available for the age group from zero to three years. Currently, the service has been expanded, being called the Youth Clinic, and serves patients from 0 to 15 years, and it also includes programs for attending specialties. According to professionals, the clinic receives patients from practically every municipality.

\section{DISCUSSION}

\section{Epidemiological profile of oral health}

In the early 1970s an epidemiological survey was carried out in which a high prevalence of caries was observed in the infant population, with a DMFT at 12 years of age of $9,8^{24}$. In 1993, another study showed a DMFT at age 12 of 4.6 , a reduction, therefore of $53 \%{ }^{25}$. Another survey carried out in $1999^{26}$ showed a mean DMFT at 12 years of 2.3, below the OMS target for the year 2000, representing a reduction of 50\% in relation to 1993 and a reduction of $79 \%$ in 27 Years (Figure 1).

Similar to other studies that have analyzed school dental services ${ }^{27-28}$, there are no differences in the prevalence of caries in schools with dental care. In the survey conducted in 1999, it was possible to disaggregate the data regarding the type of school (with or without the presence of a dentist). It can be seen from Figure 2 that there is practically no difference in the mean DMFT at 12 years. Statistical analysis performed at this age did not find a statistically significant difference.

When we analyze the distribution of the DMFT index at age 12 in both types of school, we can see a higher percentage of children with DMFT $=0$ in schools Without Surgeon-Dentist than in schools With Surgeon-
Dentist (36\% and $16.7 \%$ respectively). Although it is not possible to carry out a more detailed statistical analysis at this level according to the sample, it is curious to realize that having dental care at school can constitute a risk to oral health.

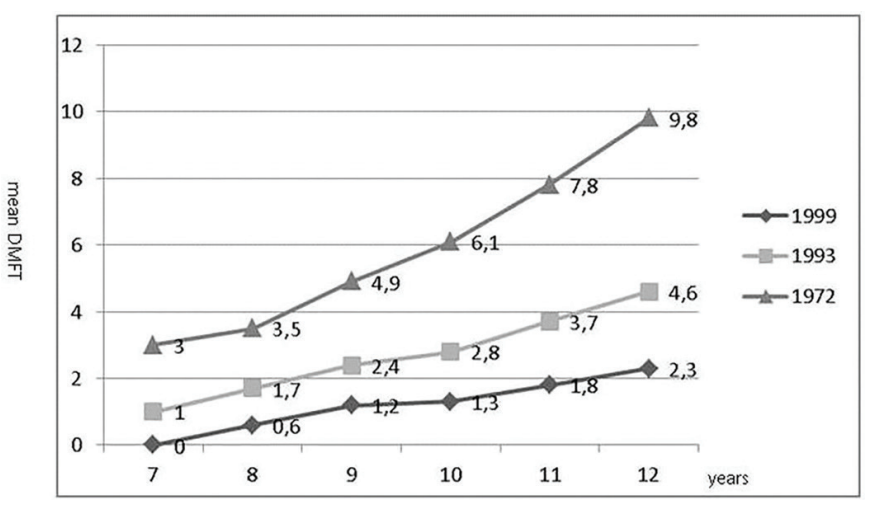

Figure 1. Prevalence of dental caries (DMFT) according to age groups between 1972 and 1999 in the municipality of Araçatuba.

Source: Saliba et al., 1981; Arcieri et al., 1998; Moimaz, 2000.

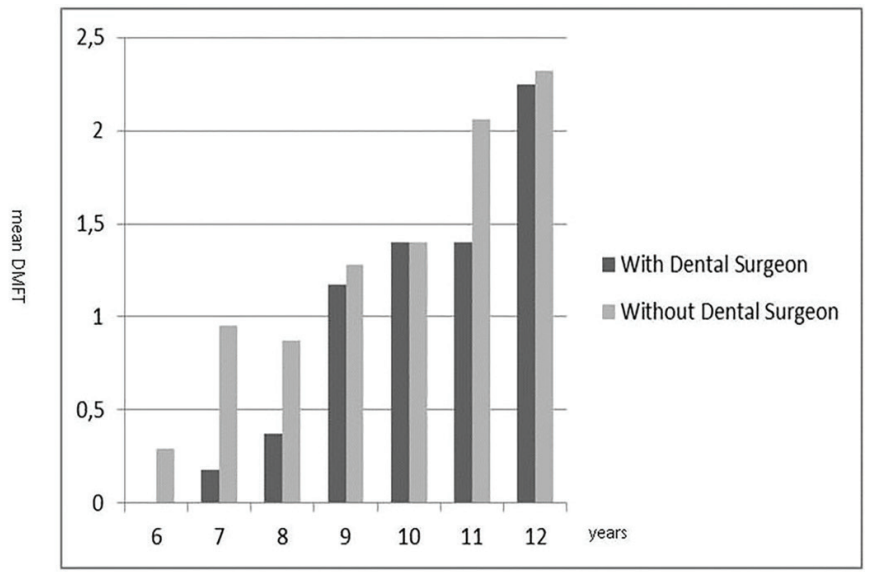

Figure 2. Prevalence of dental caries (DMFT) in 1999 in the city of Araçatuba, according to age groups in schools with and without Dental Surgeon. Source: Moimaz, 2000

In the 2010 survey of 58 public schools in Araçatuba, in pre-school children aged 4 to 6 years by FOA UNESP demonstrated that caries prevalence was $41.2 \%$ and the prevalence of both, caries lesions cavitated and not cavitated, was $43.9 \%$. The mean dmft at 4,5 and 6 years were respectively $1.18,1.65$ and 1.73 .

\section{The model of oral health care}

Public dental care is given in 1961, with the implementation of a teaching-assistance activity by the 
Dental School of Araçatuba (FOA-UNESP), the Rural Dental Service (RDS), with the purpose of providing dental care to the population of rural neighborhoods. At this time there was still no municipal system to provide dental services and an agreement was then entered into between FOA and the City Hall. The first experience happened in the rural district of Vicentinópolis, belonging to the municipality of Araçatuba. Then the service was expanded to other rural areas, such as Santo Antônio do Aracanguá, Major Prado, Taveira Engineer, Água Limpa e Prata ${ }^{29}$.

Seven years after the implementation of the RDS, the Urban Dental Service (UDS) was created, with the expansion of dental care to several entities in Araçatuba, as well as an office located in the Department of Social Dentistry ${ }^{29}$.

In addition to the dental services provided by the FOA, in the form of a teaching-service articulation, in 1989, a system of attendance to schoolchildren was initiated by the state government, the "Dental School". It was an assistance model for schoolchildren based on the incremental system, which had been implemented in several cities of the State. In addition, a basic municipal assistance network was gradually set up, where dental care was being incorporated.

In 1989, already under the UHS, the Oral Health Program of the Municipality of Araçatuba was elaborated, where the basic guidelines for the operation of dental care at the municipal level were explained. This program, except for a few minor modifications, is what has been put into practice to this day ${ }^{30}$. Also in this same year, the School Dental was municipalized, being under the responsibility of the city hall its management and maintenance, while the payment of the dental surgeons still continued to be done by the State. Currently the remuneration is carried out by the Municipality.

In 2001, the Family Health Program (FHP) was implemented, with 17 oral health teams, which is maintained until the current day.

The management and execution of actions and health services have been carried out by Social Organizations since 2009. From the year 2014, the person in charge of the basic assistance of the municipality (Family Health Strategy - FHS, Oral Health Program OHP, Support to Family Health - SFH, Popular Pharmacy Program - PPP and the Best Home Program) is the Family Health Association of São Paulo.

\section{The organization of demand in the basic network}

In the 1990s, within the basic network (the Units of Dental Care), the clientele from 3 to 18 years old and the pregnant women were prioritized. For the adult population (above 18 years of age, non-pregnant), only emergency and emergency treatment was offered at Pronto Municipal Service.

Currently, the majority of patients are scheduled for free demand during office hours and there is priority for pregnant patients. Some units schedule patients through consultation blocks (group of patients scheduled at the same time) and served on a first-come, first-served basis. For emergency and emergency treatment, the first two hours of service are made available daily. There is no nocturnal dental care in the municipal public system.

Regarding the home visits of the dental surgeons of the FHS, which should be a routine activity, it was observed that this action only occurs when the Community Health Agent, during his routine visit, perceives the need for oral care and, later, schedules the oral health team to visit the patient, who are usually bedridden or elderly patients. The resistance of this action by dentists can be explained by their culture of working on four walls.

Considering the epidemiological reality of Araçatuba, it is unlikely that the "deficits" are in the children population, since the data show a low prevalence of disease. Most of the needs are likely to be located in the adult population, which may still have a pool of accumulated needs.

In any case, it is not a matter of choosing which group to prioritize only by epidemiological reasoning or, in another way, by the logic of healthcare debt. According to Zanetti ${ }^{31}$, "the understanding of greater or lesser equity should not be based on the existence of more or less welfare debt. If this were the valid criterion, it would be more equitable to care for adults. However, just as in a 'short blanket'... welfare debt varies with the choice of offer and creates a dynamic, circular and perpetual situation: it is only to begin to care for the adults to the detriment of the children that they will quickly return to being priority".

In this way, the logic must be based on the analysis of the operative capacity allied to the epidemiological data. When analyzing the network of dental services in Araçatuba, it can be seen that its average number of dental equipment in HUS use per 100,000 inhabitants for the estimated population in 2014 is 111.7, five times higher than the São Paulo State average (22.4). 
A relevant fact to be considered in the prioritization process is that the focus on the adolescent and the adult occurs in the basic network, but there is still the attendance in the schools, exclusive for the children, that is, in a part of the network is prioritized and in the other it is exclusive. Taking into account that the smallest needs are located in the school population, this is an incomprehensible distortion. In addition, when examining the annual output of dental surgeons from schools and dental surgeons of the basic network, it is noticed that the highest productivity is found in the basic network. Considering the proportional value, that is, the procedures by dental surgeon, the advantage remains. It is recognized that dental care in schools presents greater idleness than the municipal network, due to the lower needs and the limitation of the age group. In the past it has attempted a relocation of dental surgeons from the schools to the basic network, but there was a great deal of resistance from the professionals and it was not possible to do so.

It should also be emphasized that the work of dental surgeons in schools occurs for historical reasons and not for an epidemiological criterion. It is noted that collective actions that should be in greater numbers in schools are not being a priority.

It is important to emphasize that the school can (in fact must) be used by the oral health services as a practice space, from the point of view of educational and preventive activities. It is a consolidated strategy in most of the country, with excellent results from the point of view of the reduction in the indexes of oral diseases. However, the school, as a space for curative care, in addition to reproducing an outmoded model, which has proved not to have a positive impact on the levels of disease in the child population, it runs contrary to the implementation strategies of the Health Unic System, violating the principles of universality, equity and completeness. Oral health professionals end up working in isolation way from other health professionals, and in most of the time they are not appropriate, with a lack of equipment, scrapping devices, and environments that are unfavorable to four-hand work. In the first case, because it restricts care to only a fraction of the population, although under the justification of being a prioritized clientele, which, in the case of the municipality surveyed, does not have a consistent epidemiological basis. In the second case, because it ignores the differentials of the population from the point of view of its real demands for oral health, treating almost exclusively a certain part of the population considering only operational criteria and not having, as base, social justice. Finally, full assistance is compromised to the extent that the school dental system, because it is a structure parallel to the municipal public system, practically makes any type of intersectoral action impossible. As a result of this principle, the structuring of a hierarchical network is stuck because it contains elements that work under another organizational logic.

With regard to the focus on the pregnant woman as a priority group in the basic network, it is also an organizational logic with no epidemiological basis, since pregnant women, strictly speaking, do not constitute a population group. The clipping is made as if women, being pregnant, become other beings with different demands, and as if their health situation was not the result of a lifetime. The usual justification is that the pregnant woman goes through a phase in which she is more receptive to educational actions and therefore, there is a concern that the future baby may have a mother more educated from the point of view of oral health and a less infected mouth. The mother, therefore, is seen not as a citizen who is entitled to health care, but as the repository of a privileged being who will be guaranteed his assistance.

With regard to infant care, through the municipal baby-clinic, there is no referral for the child's follow-up, although it has been transformed into a Youth Clinic, after 3 years of age there is no follow-up of this child. Caregivers seek care, if necessary, and may result in high rates of dental caries in adolescence. The location of the clinic did not obey the principles of equity and the introduction of early care (in general, a correct measure) ended up reproducing an exclusionary model, reinforcing the isolationist activity of oral health practices.

In this way, it is still, in the experience analyzed, despite the quality of the service (from a technical point of view, one might say) and the good structure available has still been put in check for some time, which makes it difficult to establish dental care based on the principle of universality and fairness. The persistence of an exclusionary model imposes a conservative and archaic trait on the care model in oral health insofar as the bases of its planning are not based on epidemiological and social criteria.

\section{CONCLUSION}

In this study about the analysis of the municipal experience of the UHS Health Care Network, it was demonstrated that traditional models still exist, which 
shows that the implementation of public models of oral health based on UHS is fraught with challenges not only because of the difficulty of to break with practices rooted in the profession and the institutions, but also by the isolationist characteristic that Dentistry has historically assumed within the health services. Despite the advances in the implementation of the FHS and the CDS, there is still a very great difficulty in establishing criteria for the organization of demand. Most of the attendance occurs by free demand, and the referral and counter referral system is incipient, compromising the service's resoluteness.

\section{REFERENCES}

1. Narvai PC. Odontologia e saúde bucal coletiva. São Paulo: Hucitec; 1994

2. Zanetti CHG, Lima MAU. Em busca de um paradigma de programação local em saúde bucal mais resolutivo no SUS. Divulg Saúde Debate. 1996;13:18-35.

3. Oliveira AGRC, Arcieri RM, Unfer B, Costa ICC, Moraes E, Saliba NA. Modelos assistenciais em saúde bucal no Brasil: tendências e perspectivas. Ação Coletiva. 1999;2(1):9-13.

4. Baldani MH, Berger Fadel CB, Possamai T, Queiroz MGS. A inclusão da odontologia no Programa Saúde da Família no Estado do Paraná, Brasil. Cad. Saúde Pública. 2005; 2(4):102635. doi: 10.1590/S0102-311X2005000400005

5. Terreri ALM, Soler ZASG. Estudo comparativo de dois critérios utilizados no Programa Saúde da Família na priorização do tratamento da cárie entre crianças de 5 a 12 anos. Cad Saúde Pública. 2008;24(7):1581-7. doi: 10.1590/S0102$311 \times 2008000700013$

6. Brasil. Câmara dos Deputados. Constituição da República Federativa do Brasil: promulgada em 5 de outubro de 1988. Brasília:IMESP; 1988[citado 2015 Out 10]. Disponível em:<http:// bd.camara.gov.br/bd/bitstream/handle/bdcamara/15261/ constituicao_federal_35ed.pdf?sequence=9>.

7. Brasil. Ministério da Saúde. $8^{\circ}$ Conferência Nacional de Saúde: relatório final. Brasília: Ministério da Saúde; 1986 [citado 2015 Out 10]. Disponível em: <http://conselho.saude.gov.br/ biblioteca/relatorios/relatorio_8.pdf>.

8. Frazão P, Narvai PC. Saúde bucal no Sistema Único de Saúde: 20 anos de lutas por uma política pública. Saúde Debate. 2009;33(81):64-71.

9. Aith FMA. Marcos legais da promoção da saúde no Brasil. Rev Med. 2013; 92(2):148-54.

10. Brasil. Ministério da Saúde. $2^{a}$ Conferência Nacional de Saúde Bucal: relatório final. Brasília: Ministério da Saúde, 1993 [citado 2015 Out 10]. Disponível em: <http://conselho.saude.gov.br/ biblioteca/Relatorios/saude_bucal.pdf $>$.

\section{Collaborators}

AG RONCALLI was responsible for the conception and design of the research, obtaining of data, analysis and interpretation of the data, statistical analysis and writing of the manuscript. SAS MOIMAZ was responsible for the conception and design of the research and writing of the manuscript. AMP GOMES did the statistical analysis and participated in writing the manuscript. CAS GARBIN and NA SALIBA were responsible for the conception and design of the research and writing of the manuscript.

11. Brasil. Ministério da Saúde. $3^{a}$ Conferência Nacional de Saúde Bucal: acesso e qualidade superando exclusão social. Brasília: Ministério da Saúde, 2005 [citado 2015 Out 10]. Disponível em: <http://conselho.saude.gov.br/biblioteca/Relatorios/saude_ bucal.pdf>

12. Martins P, Aguiar ASW. Acesso aos serviços de saúde bucal na atenção primária à saúde: avanços e desafios da $11^{\text {a }}$ região de saúde do Ceará. Sanare. 2011;10(1):6-12.

13. Souza GB, Junqueira SR, Araujo ME, Botazzo C. Práticas para a saúde: avaliação subjetiva de adolescentes. Saúde Debate. 2012;36(95):562-71.

14. Loureiro CA, Oliveira FJ. Inversão da atenção: uma estratégia para construção de modelos locais em saúde bucal. Belo Horizonte: Estação Saúde; 1995.

15. Vieira $V$, Andrade FR, Castro CGJ, Bighetti TI, Narvai PC. Municipalização de serviços de saúde segundo profissionais de saúde bucal em um município do interior do estado de São Paulo, Brasil. Saúde Soc. 2013;22(3):795-803.

16. Machado MS, Oliveira SS, Ceretta RA. A importância do cirurgião-dentista na estratégia de saúde da família. Rev Prog Resid Multiprof Atenção Básica Saúde Fam. 2013;1:110-21.

17. Botazzo C, Bertolini SR, Corvelho VM. Atenção em saúde bucal: condição atual do acesso a trabalhadores e adultos nos Sistemas Locais de Saúde. Divulg Saúde Debate. 1995;10:4353

18. Brasil. Ministério da Saúde. Saúde bucal. Brasília: Ministério da Saúde; 2006 [citado 2015 Out 12]. Disponível em: < http://dab. saude.gov.br/portaldab/biblioteca. php?conteudo=publicacoes/ cab1>

19. Brasil. Sistema Único de Saúde. Brasília: CONASS; 2007.

20. Instituto Brasileiro de Geografia e Estatísticas. Estimativa da população residente no Brasil e Unidades da Federação com data de referência em $1^{\circ}$ de julho de 2014. 2014 [citado 2014 Set 10]. Disponível em: <ftp://ftp.ibge.gov.br/Estimativas_de_ Populacao/Estimativas_2014/estimativa_dou_2014.pdf>.

21. Brasil. Controladoria-Geral da União. Araçatuba (SP): transferências por ação: exceto recursos recebidos diretamente pelo cidadão. 2013 [citado 2014 Set 11]. Disponível em: 
<http://sp.transparencia.gov.br/Ara\%C3\%A7atuba/receitas/ por-acao/acoes? exercicio=2013> .

22. Brasil. Ministério da Saúde. Cadernos de informações da saúde: São Paulo. 2014 [citado 2014 Jan 10]. Disponível em: <http:// tabnet.datasus.gov.br/tabdata/cadernos/sp.htm>.

23. Brasil. Fundação Sistema Estadual de Análise de Dados. Informações dos Municípios Paulistas: IMP. 2014 [citado 2014 Set 1]. Disponível em: <http://produtos.seade.gov.br/produtos/ $\mathrm{imp} />$.

24. Saliba NA, Saliba O, Vieira SMM, Rey CR, Arcieri RM, Ayres JPS Estado de saúde oral dos escolares da cidade de Araçatuba, estado de São Paulo, antes da introdução do flúor no sistema público de abastecimento de água. Rev Assoc Paul Cir Dent. 1981;35(2):156-9.

25. Arcieri RM, Saliba CA, Saliba NA, Moimaz SAS, Sundefeld MLMM. Redução da cárie dentária em escolares de Araçatuba, após 21 anos de fluoretação da água de abastecimento público. Rev Fluminense Saúde Coletiva. 1998;(3):41-8.

26. Moimaz SAS, Saliba NA, Tomita NE, Lopes ES. Cárie dentária aos 12 anos de idade e as metas da OMS para o ano 2000. Ciênc Saúde Coletiva. 2000;5:555.
27. Nickel DA, Lima FG, Silva BB. Modelos assistenciais em saúde bucal no Brasil. Cad Saúde Pública. 2008; 24(2):241-6. doi: 10.1590/S0102-311X2008000200002

28. Cunha BAT, Marques RAA, Castro CGJ, Narvai PC. Saúde bucal em Diadema: da odontologia escolar à estratégia saúde da família. Saúde Soc. 2011;20(4):1033-45.

29. Universidade Estadual Paulista. Serviço extra-mural odontológico - SEMO. Araçatuba: UNESP; 1997.

30. Prefeitura Municipal De Araçatuba. Programa de saúde bucal do município de Araçatuba - SP. Araçatuba: Prefeitura Municipal de Araçatuba; 1989.

31. Zanetti CHG. Saúde bucal no Programa de Saúde da Família (PSF): proposição e programação. 2000 [citado 2015 Jul 5]. Disponível em: <http://www.saudebucalcoletiva.unb.br>.

Received on: $29 / 3 / 2016$

Final version resubmitted on: 25/4/2016

Approved on: 9/5/2016 